\title{
KARAKTERISTIK HAK GUNA BANGUNAN DI ATAS TANAH HAK MILIK
}

Marthen B.Salinding

Fakultas Hukum Universitas Borneo Tarakan

Email:mhukum@ymail.com

\begin{abstract}
Abstrak
Kebutuhan akan tanah bagi dunia usaha semakin besar, sementara persedian tanah terbatas. Salah satu hak atas tanah yang digunakan oleh investor dalam menunjang usahanya adalah Hak Guna Bangunan. Hak Guna Bangunan adalah hak untuk memiliki dan mempunyai bangunan-bangunan diatas tanah yang bukan miliknya sendiri dengan jangka waktu paling lama 30 tahun. Tanah yang dapat diberikan Hak Guna bangunan adalah Tanah Negara, tanah Hak Pengelolaan dan tanah Hak Milik

Hak Milik sebagai salah satu objek pemberian Hak Guna Bangunan adalah hak turun temurun, terkuat dan terpenuh yang dapat dipunyai orang atas tanah dengan mengingat ketentuan dalam Pasal 6 UUPA.

Hak Guna Bangunan di atas tanah Hak Milik mempunyai sifat khusus karena pemberian haknya dituangkan dalam bentuk akta pemberian Hak Guna Bangunan di atas tanah hak milik, yang mengatur secara khusus kesepakatan para pihak dalam rangka memenuhi asas kebebasan berkontrak. Disamping itu dalam membuat akta pemberian Hak Guna Bangunan di atas tanah hak milik dapat diatur secara khusus mengenai isi akta dengan menyimpang dari peraturan perundang-undangan yang berlaku. Bilamana pemegang Hak Guna Bangunan bermaksud membebani hak tanggungan dan mengalihkan hak ini harus memperoleh persetujuan dari pemegang hak milik. Hal ini berbeda dengan Hak Guna Bangunan di atas tanah negara. Hak Guna Bangunan di atas tanah negara dapat dibebani hak tanggungan dan dialihkan tanpa harus mendapat persetujuan pihak lain

Kata Kunci; Hak Guna Usaha, Hak Milik, Tanah
\end{abstract}

\section{Abstract}

The need for land for the business world is getting bigger, while the land supply is limited. One of the rights to land used by investors to support their business is the building rights. The building rights.is the right to own and own buildings on land which is not his own with a maximum period of 30 years. The land which can be granted of the right building is the State Land, the land of management rights and the land of property rights 
Teh Building Right as one of the objects granting of Right Building is the hereditary, strongest and most fulfilled right which can be owned by people on the land keeping in mind the provisions in Article 6 of the Basic Agrarian Law.

The Building Right on the land Property rights have special characteristics because the granting of their rights is set forth in the form of deed granting of building Right on the land of property rights, which specifically regulates the agreement of the parties in order to fulfill the principle of freedom of contract. In addition, in making the deed granting of Building Right on the land of proprietary rights can be arranged specifically about the contents of the deed by deviating from the prevailing laws and regulations. Where a Building Rights Holders intend to impose a mortgage right and transfer this right shall obtain the consent of the right holder. This is different from the building right on state land. The buildings rights on state land may be borne by mortgages and transferred without obtaining the consent of others

Keywords; Building Right, Property Right, Land

\section{PENDAHULUAN}

UUPA Pasal 20 mengatur tentang Hak Milik (HM). Hak milik adalah hak turun-temurun, terkuat dan terpenuh yang dapat dipunyai orang atas tanah, dengan mengingat ketentuan dalam pasal 6 dan Hak milik dapat beralih dan dialihkan kepada pihak lain. Dalam pasal ini disebutkan, sifat-sifat dari pada hak milik yang membedakan dengan hak-hak lainnya. Hak milik adalah hak "terkuat dan terpenuh"yang dapat dipunyai orang atas tanahTetapi pengertian terkuat, terpenuh dan paling sempurna tidaklah berarti bahwa si pemilik tanah itu boleh bertindak atau melakukan apa saja atas tanahnya. UUPA pasal 6 mengatur bahwa hak milik yang mempunyai fungsi sosial seperti juga semua hak atas tanah lainnya mengandung arti bahwa hak milik atas tanah tersebut di samping hanya memberikan manfaat bagi pemiliknya, harus diusahakan pula agar sedapat mungkin dapat bermanfaat pula bagi orang lain atau kepentingan umum dan penggunaan hak milik tersebut tidak boleh menggangu ketertiban umum. Adrian Sutedi dalam Bukunya yang berjudul Peralihan Hak Atas Tanah dan Pendaftarannya, yang menyatakan bahwa Indonesia adalah "Negara Hukum yang memberikan jaminan dan memberikan perlindungan atas hak-hak warga 
negara, untuk mendapatkan, mempunyai dan menikmati hak milik."71 Hak Milik dalam lingkup kali ini adalah Hak Milik atas Tanah.

Hak atas tanah ialah hak yang memberi wewenang kepada pemiliknya untuk mempergunakan atau mengambil manfaat dari tanah yang dihakinya. Ciri khasnya ialah pemilik hak berwenang untuk mempergunakan atau mengambil manfaat dari tanah yang dihakinya. ${ }^{72}$ Sedangkan Hak Guna Bangunan sebagaimana yang dimaksud dalam Pasal 35 UUPA adalah hak untuk memiliki dan mempunyai bangunan-bangunan diatas tanah yang bukan miliknya sendiri dengan jangka waktu paling lama 30 tahun. Sedangkan Hak Milik sebagaimana disebutkan dalam Pasal 20 UUPA adalah hak turun temurun, terkuat dan terpenuh yang dapat dipunyai orang atas tanah dengan mengingat ketentuan dalam Pasal 6 UUPA.

Hak Milik dalam suatu bangsa menjadi sangat penting terutama bagi masyarakat yang sedang membangun ke arah perkembangan, perdagangan, parawisata, dan industry yang kesemuanya memerlukan infrastruktur pendukung. Tentu saja yang di maksudkan dalam hal ini adalah Hak Milik atas tanah. Sementara tanah yang merupakan hal pokok bagi manusia menghadapai beberapa macam masalah antara lain:

a. Keterbatasan tanah, baik dalam jumlah maupun kualitas dibanding dengan kebutuhan yang harus dipenuhi;

b. Pergeseran pola hubungan antara pemilik tanah dan tanah sebagai akibat perubahan-perubahan yang ditimbulkan oleh proses pembangunan dan perubahan-perubahan sosial pada umumnya;

c. Tanah disatu pihak telah tumbuh sebagai benda ekonomi yang sangat penting, pada lain pihak telah tumbuh sebagai bahan perniagaan dan objek spekulasi;

d. Tanah disatu pihak harus dipergunakan dan dimanfaatkan untuk sebesar-sebesarnya kesejahteraan rakyat lahir, batin, adil dan merata, sementara di lain pihak harus dijaga kelestariannya. ${ }^{73}$

71 Adrian Sutedi,2006,Peralihan Hak Atas Tanah dan Pendaftarannya, Sinar Grafika, Jakarta.,2006, h. 1

${ }^{72}$ Effendi Perangin, Hukum Agraria di Indonesia (Suatu Telaah dari Sudut Pandang Praktisi Hukum), Cetakan ke-3, Jakarta, Rajawali, 1991, hal. 229.

${ }^{73}$ Adrian Sutedi, Loc.cit 
Salah satu jenis hak atas tanah yang digunakan oleh investor dalam berbagai sektor ekonomi untuk mendukung usahanya adalah Hak Guna Bangunan (HGB). Pasal 36 UUPA dan Pasal 19 Peraturan Pemerintah Nomor 40 Tahun 1996 menyatakan yang dapat menjadi pemegang Hak Guna Bangunan adalah Warga Negara Indonesia dan badan hukum yang didirikan menurut hukum Indonesia dan berkedudukan di Indonesia,sedangkan objek HGB adalah tanah negara, tanah Hak pengelolaan dan tanah Hak Milik.

Terkait dengan HGB, Peraturan Pemerintah Nomor 40 Tahun 1996 tentang Hak Guna Usaha, Hak Guna Bangunan dan Hak Pakai atas tanah telah diatur dengan jelas. Namun dalam pelaksanannya aturan tersebut masih belum dapat diimplemantasikan dengan baik. Karena berdasarkan amanat Pasal 50 ayat (1) UUPA yang menyatakan bahwa "Ketentuan-ketentuan lebih lanjut mengenai hak milik diatur dengan Undang-undang ". Selanjutnya penjelasan Pasal 50 ayat (1) disebutkan,"Sebagai konsekwensi, bahwa dalam undangundang ini hanya dimuat pokok-pokoknya saja dari hukum agraria yang baru".

HGB di atas tanah hak milik pada satu sisi bermaksud melindungi kepentingan pemegang hak milik yang secara umum adalah masyarakat hukum adat, masyarakat yang ekonominya lemah atau masyarakat lokal setempat sedangkan badan hukum secara umum adalah pemilik modal yang kuat, sehingga dengan demikian pemberian HGB di atas tanah hak milik bertujuan agar nantinya setelah HBG berakhir maka hak miliknya akan muncul kembali, dengan demikian pemegang hak milik maupun ahli warisnya masih memiliki kesempatan untuk menjadi pemegang hak miliknya kembali setelah HGB berakhir

HGB di atas Tanah Hak milik memiliki karakteristik yang berbeda dengan HGB di atas Tanah negara maupun HGB di atas tanah hak pengelolaan. HGB di atas tanah Hak Milik di dasarkan pada adanya perjanjian antara pemegang HGB dengan pemegang hak milik dan tunduk pada hukum privat. Oleh karena itulah menarik untuk dikaji. 
Berdasarkan pemaparan di atas, makalah ini memberikan perumusan masalah sebagai berikut; Pertama, bagaimana pengaturan HGB di atas tanah Hak Milik,? Kedua, bagaimana karakteristik HGB di atas tanah Hak Milik?

\section{PEMBAHASAN}

\section{Pengaturan Pemberian Hak Guna Bangunan Atas Tanah Hak Milik}

Pengaturan Pemberian HGB atas tanah hak milik pada dasarnya merupakan pembebanan yang dilakukan oleh pemegang hak milik atas tanah miliknya. Karena itu pemberian hak ini dilakukan dengan suatu perjanjian antara pemegang hak milik dan calon pemegang HGB yang dituangkan dalam akta yang dibuat oleh Pejabat Pembuat Akta Tanah.

Pasal 37 UUPA menegaskan bahwa Hak Guna Bangunan terjadi pada tanah yang dikuasai langsung oleh negara atau tanah milik orang lain. Sedangkan Pasal 21 Peraturan Pemerintah Nomor 40 Tahun 1996 menegaskan bahwa tanah yang dapat diberikan dengan Hak Guna Bangunan (objek Hak Guna Bangunan) adalah :

1. Tanah Negara ;

2. Tanah Hak Pengelolaan ;

3. Tanah Hak Milik ;

Berdasarkan Pasal 32 Peraturan Pemerintah Nomor 40 tahun 1996 tentang

Hak Guna Usaha, Hak Guna Bangunan dan Hak Pakai Atas Tanah, pemegang Hak Guna Bangunan mempunyai hak :

1. Menguasai dan mempergunakan tanah selama waktu tertentu.

2. Mendirikan dan mempunyai bangunan untuk keperluan pribadi atau keperluan usahanya.

3. Mengalihkan Hak Guna Bangunan tersebut kepada pihak lain melalui suatu perjanjian.

Pasal 22 Peraturan Pemerintah No. 40 Tahun 1996 menentukan bahwa: 
(1) Hak Guna Bangunan atas tanah Negara diberikan dengan keputusan pemberian hak oleh Menteri atau pejabat yang ditunjuk.

(2) Hak Guna Bangunan atas tanah Hak Pengelolaan diberikan dengan keputusan pemberian hak oleh Menteri atau pejabat yang ditunjuk berdasarkan usul pemegang Hak Pengelolaan.

(3) Ketentuan mengenai tata cara dan syarat permohonan dan pemberian Hak Guna Bangunan atas tanah Negara dan atas tanah Hak Pengelolaan diatur lebih lanjut dengan Keputusan Presiden.

Maksud dari pasal tersebut bahwa pada dasarnya HGB yang diberikan di atas tanah Negara atau tanah Hak Pengelolaan diberikan berdasarkan keputusan Menteri Negara Agraria/Kepala Badan Pertanahan Nasional, dengan memperhatikan ketentuan yang diatur dalam Peraturan Menteri Negara Agraria / Kepala Badan Pertanahan Nasional No. 3 Tahun 1999 tentang Pelimpahan Kewenangan Pemberian dan Pembatalan Keputusan Pemberian Hak Atas Tanah Negara, khususnya ketentuan dalam Pasal 4. Kepala Kantor Pertanahan Kabupaten/Kotamadya memberi keputusan mengenai :

1) pemberian Hak Guna Bangunan atas tanah yang luasnya tidak lebih dari 2000 m2 (dua ribu meter persegi), kecuali mengenai tanah bekas Hak Guna Usaha;

2) semua pemberian Hak Guna Bangunan atas tanah Hak Pengelolaan. Menteri Negara Agraria/Kepala Badan Pertanahan Nasional menetapkan pemberian hak atas tanah yang diberikan secara umum.

Dari rumusan pasal tersebut, dapat diketahui bahwa terhadap pemberian HGB.

1) sampai dengan $2000 \mathrm{m3}$, pemberian Hak Guna Bangunan atas tanah Negara dilakukan oleh Kepala Kantor Pertanahan Kabupaten/ Kotamadya;

2) mulai dari 2000 m2 hingga 150.000 m2, pemberian Hak Guna Bangunan atas tanah Negara dilakukan oleh Kepala Kantor Wilayah Badan Pertanahan Nasional Propinsi; 
3) di atas $150.000 \mathrm{~m} 2$, pemberian Hak Guna Bangunan atas tanah Negara dilakukan oleh Kepala Badan Pertanahan Nasional/Menteri Negara Agraria.

4) pemberian Hak Guna Bangunan atas tanah Hak Pengelolaan dilakukan oleh Kepala Kantor Pertanahan Kabupaten / Kotamadya. ${ }^{74}$

Sementara itu pemberian Hak Guna Bangunan di atas tanah Hak Milik, dapat ditemukan penjelasannya dalam Pasal 24 Peraturan Pemerintah No. 40 Tahun 1996, yang berbunyi sebagai berikut :

(1) Hak Guna Bangunan atas tanah Hak Milik terjadi dengan pemberian oleh pemegang Hak Milik dengan akta yang dibuat oleh Pejabat Pembuat Akta Tanah.

(2) Pemberian Hak Guna Bangunan atas tanah Hak Milik sebagaimana dimaksud dalam ayat (1) wajib didaftarkan pada Kantor Pertanahan.

(3) Hak Guna Bangunan atas tanah Hak Milik mengikat pihak ketiga sejak didaftarkan sebagaimana dimaksud dalam ayat (2).

(4) Ketentuan mengenai tata cara pemberian dan pendaftaran Hak Guna Bangunan atas tanah Hak Milik diatur lebih lanjut dengan Keputusan Presiden

Berdasarkan ketentuan tersebut jelas bahwa pemberian HGB di atas tanah Hak Milik lahir pada saat dibuatnya akta pemberian HGB tersebut oleh Pejabat Pembuat Akta Tanah (PPAT). Pendaftaran yang dilakukan adalah hanya untuk mengikat pihak ketiga.

Ketentuan ini berbeda dari pemberian Hak Opstal di atas eigendom barang tidak bergerak, khususnya tanah menurut BW. Dalam pandangan BW, Hak Opstal baru lahir pada saat didaftarkan menurut ketentuan Pasal 620 BW.

Menurut Pasal 24 PP No 40 Tahun 1996, pemberian HGB di atas tanah Hak Milik terjadi pada saat dibuatnya akta pemberian HGB di atas tanah Hak Milik oleh PPAT. Pendaftaran yang dilakukan di kantor pertanahan adalah hanya untuk mengikat pihak ketiga, dan menjadi sahnya pemberian tersebut. 
Peraturan Perundang-undangan ini sebetulnya mengamanatkan bahwa untuk tata cara pemberian dan pendaftaran pemberian HGB di atas tanah Hak Milik akan diatur lebih lanjut dengan Keputusan Presiden. Namun sampai saat aturan tersebut belum juga ada sehingga dalam pelaksanaannya sering menimbulkan permasalahan.

Menurut Pasal 120 Peraturan Menteri Agraria/Kepala BPN No 3 Tahun 1997, pembebanan Hak Guna Bangunan atau Hak Pakai atas Hak Milik harus didaftarkan ke kantor pertanahan setempat oleh pemegang Hak Milik atau penerima Hak Guna Bangunan atau Hak Pakai, dengan melampirkan :

a. Surat permohonan pendaftaran Hak Guna Bangunan atau Hak Pakai atas Hak Milik;

b. Sertipikat Hak Milik yang dibebani dengan Hak Guna Bangunan atau Hak Pakai;

c. Akta PPAT bersangkutan;

d. Identitas penerima Hak Guna Bangunan atau Hak Pakai;

e. Surat kuasa tertulis dari pemohon, apabila permohonan tersebut diajukan oleh orang lain;

f. Bukti pelunasan pembayaran bea perolehan hak atas tanah dan bangunan;

g. Bukti pelunasan pembayaran PPh.

Pendaftaran pembebanan hak tersebut dicatat dalam buku tanah hak atas tanah pada kolom yang telah disediakan. Hak Guna Bangunan atau Hak Pakai, dibuatkan buku tanah, surat ukur tersendiri, dan diterbitkan sertipikatnya atas nama pemegang haknya.

\section{Karakteristik Hak Guna Bangunan di atas Tanah Hak Milik}

\section{a. Hak Guna Bangunan di Atas Tanah Hak Milik Dibatasi Waktu}

Hak Guna Bangunan adalah salah satu hak atas tanah lainnya yang diatur dalam Undang-Undang Pokok Agraria. Menurut ketentuan Pasal 35 Undang Undang Pokok Agraria yang menentukan sebagai berikut : 
(1) Hak Guna Bangunan adalah hak untuk mendirikan dan mempunyai bangunan-bangunan atas tanah yang bukan miliknya sendiri, dengan jangka waktu paling lama 30 tahun.

(2) Atas permintaan pemegang hak dan dengan mengingat keperluan serta keadaan bangunan-bangunannya, jangka waktu tersebut dalam ayat (1) dapat diperpanjang dengan waktu paling lama 20 tahun.

(3) Hak Guna Bangunan dapat beralih dan dialihkan kepada pihak lain.

Sementara itu R. Roestandi Ardiwilaga mengemukakan hal yang senada ketentuan Pasal 35 ayat (1) UUPA bahwa Hak Guna Bangunan mempunyai pengertian sebagai hak untuk mendirikan dan mempunyai bangunan di atas tanah yang bukan miliknya sendiri dengan jangka waktu yang telah ditentukan paling lama 30 tahun. ${ }^{75}$ Pemilik bangunan berbeda dari pemilik hak atas tanah bangunan tersebut didirikan. Ini berarti seorang pemegang Hak Guna Bangunan adalah berbeda dari pemegang Hak Milik atas bidang tanah tempat bangunan tersebut didirikan, atau dalam arti yang lebih umum, pemegang hak guna bangunan bukanlah pemegang Hak Milik dari tanah tempat bangunan tersebut didirikan. ${ }^{76} \mathrm{Hal}$ ini dimungkinkan berdasarkan prinsip pemisahan horisontal yang dianut dalam UUPA.

Hak Guna Bangunan dapat diberikan untuk jangka waktu 20 tahun dan paling lama 30 tahun dan dapat diperpanjang dengan waktu paling lama 20 tahun. ${ }^{77}$ Atas permintaan pemegang hak dan dengan mengingat keperluan serta keadaan bangunan-bangunannya, maka jangka waktu tersebut dapat diperpanjang dengan jangka waktu paling lama 20 tahun. ${ }^{78}$

Ketentuan Pasal 25 Peraturan Pemerintah No. 40 Tahun 1996 mengatur mengenai jangka waktu pemberian Hak Guna Bangunan berbunyi sebagai berikut :

75 R. Roestandi Ardiwilaga, Hukum Agraria Indonesia Dalam Teori Dan Peaktek, Masa Baru, Bandung, 1060, h. 30

76 Kartini Mukjadi dan Gunawan Widjaya, (II) Hak-Hak Atas Tanah. Kencana, Jakarta, 2007, h. 190.

77 Eddy Ruchiyat, Politik Pertanahan,Alumni, Bandung 1989, h. 18.

78 G. Kartasapoetra, Hukum Tanah, Rineka Cipta, Bandung, 1992, h. 10. 
(1) Hak Guna Bangunan sebagaimana dimaksud dalam Pasal 22 diberikan untuk jangka waktu paling lama tiga puluh tahun dan dapat diperpanjang untuk jangka waktu paling lama dua puluh tahun.

(2) Sesudah jangka waktu Hak Guna Bangunan dan perpanjangannya sebagaimana dimaksud dalam ayat (1) berakhir, kepada bekas pemegang hak dapat diberikan pembaharuan hak Guna Bangunan di atas tanah yang sama.

Pada Pasal 26 Peraturan Pemerintah Nomor 40 Tahun 1996 menentukan:

(1) Hak Guna Bangunan atas tanah Negara sebagaimana dimaksud dalam Pasal 22, atas permohonan pemegang hak dapat diperpanjang atau diperbaharui, jika memenuhi syarat:

a. tanahnya masih dipergunakan dengan baik sesuai dengan keadaan, sifat dan tujuan pemberian hak tersebut ;

b. syarat-syarat pemberian hak tersebut dipenuhi dengan baik oleh pemegang hak ;

c. pemegang hak masih memenuhi syarat sebagai pemegang hak sebagaimana dimaksud dalam pasal 19; dan

d. tanah tersebut masih sesuai dengan Rencana Tata Ruang Wilayah yang bersangkutan.

(2) Hak Guna Bangunan atas tanah Hak Pengelolaan diperpanjang atau diperbaharui atas permohonan pemegang Hak Guna Bangunan setelah mendapat persetujuan dari pemegang Hak Pengelolaan.

Maksud dari pasal tersebut hanya Hak Guna Bangunan yang diberikan di atas tanah negara dan tanah Hak Pengelolaan saja yang dapat diperpanjang, sedangkan Hak Guna Bangunan yang diberikan di atas tanah Hak Milik tidak dapat diperpanjang melainkan hanya diperbaharui setelah berakhirnya jangka waktu yang ditetapkan dalam pemberiannya tersebut.

Berdasarkan uraian di atas dapat dipahami bahwa pemberian Hak Guna Bangunan atas Tanah Negara dan Hak Pengelolaan tunduk kepada hukum publik, sedangkan pemberian Hak Guna Bangunan Atas Tanah Hak Milik tunduk pada Hukum Privat.

Baik Hak Guna Bangunan atas Negara, Hak Pengelolaan Maupun Hak Guna Bangunan atas Tanah Hak Milik wajib didaftarkan oleh pemegang hak Guna Bangunan dan kepada diberikan sertipikat Hak Guna Bangunan. 


\section{b. Hak Guna Bangunan di Atas Tanah Hak Milik dapat beralih dan}

\section{diaihkan.}

Pasal 35 ayat (3) Undang-Undang Pokok Agraria secara tegas menyatakan bahwa HGB dapat beralih dan dialihkan kepada pihak lain. Makna kata beralih adalah suatu peristiwa hukum yang tidak disengaja oleh para pihak dengan meninggalnya pemegang hak guna bangunan. Hal ini berbeda dengan makna dialihkan. Dialihkan adalah perbuatan hukum yang bersifat sengaja untuk mengalihkan Hak Guna Bangunan kepada pihak lain seperti jual beli, tukar menukar, wakaf dan lain-lain. Ketentuan ini selanjutnya dipertegas kembali dalam Pasal 34 Peraturan Pemerintah No. 40 Tahun 1996, yang menentukan :

(1) Hak Guna Bangunan dapat beralih dan dialihkan kepada pihak lain.

(2) Peralihan Hak Guna Bangunan terjadi karena :

a. jual-beli;

b. tukar-menukar;

c. penyertaan dalam modal;

d. hibah;

e. pewarisan.

(3) Peralihan Hak Guna Bangunan sebagaimana dimaksud dalam ayat (2) harus didaftarkan pada Kantor Pertanahan.

(4) Peralihan Hak Guna Bangunan karena jual-beli kecuali jual-beli melalui lelang, tukar-menukar, penyertaan dalam modal, dan hibah harus dilakukan dengan akta yang dibuat oleh Pejabat Pembuat Akta Tanah.

(5) Jual-beli yang dilakukan melalui pelelangan dibuktikan dengan Berita Acara Lelang.

(6) Peralihan Hak Guna Bangunan karena pewarisan harus dibuktikan dengan surat wasiat atau surat keterangan waris yang dibuat oleh instansi yang berwenang.

(7) Peralihan Hak Guna Bangunan atas tanah Hak Pengelolaan harus dengan persetujuan tertulis dan pemegang Hak Pengelolaan.

(8) Peralihan Hak Guna Bangunan atas tanah Hak Milik harus dengan persetujuan tertulis dan pemegang Hak Milik yang bersangkutan.

Berdasarkan ketentuan dari pasal tersebut dapat dijelaskan bahwa Undang-Undang secara tegas membedakan syarat peralihan Hak Guna Bangunan 
atas tanah Negara dengan HGB yang diberikan di atas tanah Hak Pengelolaan maupun terhadap HGB yang diberikan di atas tanah Hak Milik. Peralihan HGB atas tanah Hak Pengelolaan harus dengan persetujuan tertulis terlebih dahulu dari pemegang Hak Pengelolaan. Demikian pula dengan peralihan Hak Guna Bangunan atas tanah Hak Milik harus dengan persetujuan tertulis terlebih dahulu dari pemegang Hak Milik yang bersangkutan. Oleh karena pemberian Hak Guna Bangunan atas tanah Hak Milik lahir dari perjanjian, maka sebagai konsekuensi dari sifat perjanjian itu sendiri. Pemegang Hak Milik dan pemegang Hak Guna Bangunan di atas tanah tersebut, termasuk peralihannya. Sebagaimana halnya peralihan Hak Milik dan Hak Guna Usaha, peralihan HGB ini pun wajib didaftarkan.

Ketentuan mengenai pendaftaran peralihan Hak Guna Bangunan juga diatur dalam ketentuan yang sama seperti halnya peralihan Hak Milik dan Hak Guna Usaha, yaitu mulai dari Pasal 37 hingga Pasal 46 Peraturan Pemerintah No. 24 Tahun 1997.

Dari rangkaian pasal-pasal tersebut di atas, ada beberapa hal yang dapat dipahami sebagai berikut:

a. Peralihan Hak Guna Bangunan, yang dilakukan dengan cara jual beli, tukar menukar, hibah, pemasukan dalam perusahaan dan perbuatan hukum pemindahan hak lainnya, kecuali pemindahan hak melalui lelang hanya dapat didaftarkan jika dibuktikan dengan akta yang dibuat oleh PPAT (Pejabat Pembuat Akta Tanah) yang berwenang. Dengan demikian berarti setiap peralihan Hak Guna Bangunan, yang dilakukan dalam bentuk jual-beli, tukar-menukar atau hibah harus dibuat dihadapan PPAT. Jual-beli, tukar-menukar atau hibah ini, dalam konsepsi hukum adat adalah suatu perbuatan hukum yang bersifat terang dan tunai. Dengan terang dimaksudkan bahwa perbuatan hukum tersebut harus dibuat di hadapan pejabat yang berwenang untuk menyaksikan dilaksanakan atau dibuatnya perbuatan hukum tersebut. Tunai diartikan 
bahwa dengan selesainya perbuatan hukum dihadapan PPAT berarti pula selesainya tindakan hukum yang dilakukan dengan segala akibat hukumnya. Ini berarti perbuatan hukum tersebut tidak dapat dibatalkan kembali, kecuali terdapat cacat cela secara substansi mengenai Hak Guna Bangunan yang dialihkan tersebut, atau cacat mengenai kecakapan dan kewenangan bertindak atas bidang tanah tersebut.

b. Dengan demikian berarti, agar peralihan Hak Guna Bangunan tersebut dapat terselenggara secara benar, maka seorang PPAT yang akan membuat peralihan Hak Guna Bangunan tersebut harus memastikan kebenaran mengenai Hak Guna Bangunan yang akan dialihkan tersebut, dan mengenai kecakapan dan kewenangan bertindak dari mereka yang akan mengalihkan dan menerima pengalihan hak atas tanah tersebut. Sehubungan dengan objek hak atas tanah yang dipindahkan, PPAT harus memeriksa kebenaran dari dokumen-dokumen yang berhubungan dengan Hak Guna Bangunan yang akan dialihkan tersebut. Dalam hal surat tersebut tidak dapat diserahkan, atau tidak ada, maka PPAT wajib menolak membuat akta pemindahan Hak Guna Bangunan yang akan dialihkan tersebut. ${ }^{79}$

Sehubungan dengan subjek hukum yang akan mengalihkan, maka PPAT harus memeriksa mengenai kewenangan dari pihak yang akan mengalihkan dan yang akan menerima peralihan Hak Guna Bangunan tersebut. Jika subjek hukum yang akan mengalihkan tidak berhak atau berwenang, maka pengalihan tidak dapat dilakukan. Jika subjek hukum yang akan menerima pengalihan bukanlah subjek hukum yang diperkenankan sebagai pemegang Hak Guna Bangunan, maka harus diperhatikan ketentuan yang diatur dalam Keputusan Menteri Negara Agraria/Kepala Badan Pertanahan Nasional Nomor 16 Tahun 1997 tentang Perubahan Hak Milik Menjadi Hak Guna Bangunan atau Hak Pakai dan 
Hak Guna Bangunan Menjadi Hak Pakai. Pada Pasal 2 Keputusan Menteri Negara Agraria/Kepala Badan Pertanahan Nasional Nomor 16 Tahun 1997 ditentukan:

(1) Permohonan pendaftaran perubahan Hak Milik menjadi Hak Guna Bangunan atau Hak Pakai, dan perubahan Hak Guna Bangunan menjadi Hak Pakai sebagaimana dimaksud dalam Pasal 1 ayat (1) diajukan kepada Kepala Kantor Pertanahan setempat dengan disertai :

a. Sertipikat Hak Milik atau Hak Guna Bangunan yang dimohon perubahan haknya, atau bukti pemilikan tanah yang bersangkutan dalam hal Hak Milik yang belum terdaftar;

b. Kutipan Risalah Lelang yang dikeluarkan oleh pejabat lelang apabila hak yang bersangkutan dimenangkan oleh badan hukum dalam suatu pelelangan umum;

c. Surat persetujuan dari pemegang Hak Tanggungan,apabila hak atas tanah tersebut dibebani Hak Tanggungan,

d. Bukti identitas pemohon.

Kemudian Pasal 3 Keputusan Menteri Negara Agraria/Kepala Badan

Pertanahan Nasional Nomor 16 Tahun 1997 menentukan:

(1) Atas permohonan pendaftaran perubahan hak sebagaimana dimaksud dalam Pasal 2 ayat (1) Kepala Kantor Pertanahan mengeluarkan perintah setor pungutan sesuai ketentuan yang berlaku.

(2) Setelah diterima tanda bukti setor pungutan sebagaimana dimaksud ayat (1) Kepala Kantor Pertanahan mendaftar perubahan Hak Milik menjadi Hak Guna Bangunan atau Hak Pakai, atau perubahan Hak Guna Bangunan menjadi Hak Pakai, sesuai ketentuan di dalam Peraturan Menteri Negara Agraria/Kepala Badan Pertanahan Nasional Nomor 3 Tahun 1997 tentang Ketentuan Pelaksanaan Peraturan Pemerintah Nomor 24 Tahun 1997 tentang Pendaftaran tanah, dengan ketentuan bahwa permohonan pendaftaran perubahan hak sebagaimana dimaksud dalam Pasal 2 ayat (1) berlaku sebagai keterangan melepaskan hak atas tanah semula sebagaimana dimaksud dalam Pasal 131 Peraturan Menteri Negara Agraria/Kepala Badan Pertanahan Nasional Nomor 3 Tahun1997.

Dengan memperhatikan ketentuan dalam Pasal 1 ayat (3) Keputusan Menteri Negara Agraria/Kepala Badan Pertanahan Nasional Nomor 16 Tahun 1997 yang menyatakan bahwa : 
Untuk perubahan Hak Guna Bangunan menjadi Hak Pakai sebagaimana dimaksud ayat (1) huruf b pemohon wajib membayar uang pemasukan kepada Negara dengan memperhitungkan uang pemasukan yang sudah dibayar kepada negara untuk memperoleh Hak Guna Bangunan yang bersangkutan.

Berdasarkan rumusan dari pasal tersebut mengandung makna dalam hal subjek hukum yang akan menerima pengalihan bukanlah subjek hukum yang berhak untuk menjadi pemegang Hak Guna Bangunan, maka haruslah terlebih dahulu dilakukan pelepasan Hak Guna Bangunan tersebut, baru selanjutnya diberikan kepada penerima hak tersebut hak atas tanah yang sesuai dengan peruntukkannya dan yang boleh diberikan kepada penerima hak atas tanah tersebut. 80

Satu hal lagi yang perlu diperhatikan adalah bahwa, jika hal tersebut tidak dilakukan, ketentuan Pasal 40 Undang-Undang Pokok Agraria jo. Pasal 36 Ayat (2) Undang-Undang Pokok Agraria menentukan :

Hak Guna Bangunan hapus karena :

a. jangka waktunya berakhir;

b. dihentikan sebelum jangka waktunya berakhir karena sesuatu syarat tidak dipenuhi;

c. dilepaskan oleh pemegang haknya sebelum jangka waktunya berakhir;

d. dicabut untuk kepentingan umum;

e. ditelantarkan;

f. tanahnya musnah;

g. ketentuan dalam Pasal 36 ayat (1)

Orang atau badan hukum yang mempunyai Hak Guna Bangunan dan tidak lagi memenuhi syarat-syarat yang tersebut dalam ayat (1) pasal ini dalam jangka waktu 1 tahun wajib melepaskan atau mengalihkan hak itu kepada pihak lain yang memenuhi syarat. Ketentuan ini berlaku juga terhadap pihak yang memperoleh Hak Guna Bangunan, jika ia tidak memenuhi syarat-syarat tersebut. Jika Hak Guna Bangunan yang bersangkutan tidak dilepaskan atau dialihkan

80 Ibid, h. 212. 
dalam jangka waktu tersebut, maka hak itu hapus karena hukum, dengan ketentuan, bahwa hak-hak pihak lain akan diindahkan, menurut ketentuanketentuan yang ditetapkan dengan Peraturan Pemerintah.

Maksud dari Pasal 40 Undang-Undang Pokok Agraria jo. Pasal 36 ayat (2) Undang-Undang Pokok Agraria dapat diketahui, bahwa apabila tidak dilakukan pelepasan hak dan permohonan hak baru (yang sesuai), yang berarti pihak yang menerima pengalihan hak, bukanlah subjek hukum yang berhak untuk menjadi pemegang Hak Guna Bangunan, maka Hak Guna Bangunan demi hukum akan hapus.

Ketentuan tersebut juga dipertegas kembali dalam Pasal 35 jo. Pasal 20 ayat (2) Peraturan Pemerintah No. 40 Tahun 1996. Pasal 35 menentukan sebagai berikut:

(1) Hak Guna Bangunan hapus karena :

a. berakhirnya jangka waktu sebagaimana ditetapkan dalam keputusan pemberian atau perpanjangannya atau dalam perjanjian pemberiannya ;

b. dibatalkan oleh pejabat yang berwenang, pemegang Hak Pengelolaan atau pemegang Hak Milik sebelum jangka waktunya berakhir, karena:

1) tidak dipenuhinya kewajiban-kewajiban pemegang hak dan/atau dilanggarnya ketentuan-ketentuan sebagaimana dimaksud dalam Pasal 30, Pasal 31 dan Pasal 32 ; atau

2) tidak dipenuhinya syarat-syarat atau kewajiban-kewajiban yang tertuang dalam perjanjian pemberian Hak Guna Bangunan antara pemegang Hak Guna Bangunan dan pemegang Hak Milik atau perjanjian penggunaan tanah Hak Pengelolaan; atau

3) putusan pengadilan yang telah mempunyai kekuatan hukum yang tetap;

c. dilepaskan secara sukarela oleh pemegang haknya sebelum jangka waktu berakhir ;

d. dicabut berdasarkan Undang-Undang Nomor 20 Tahun 1961;

e. ditelantarkan;

f. tanahnya musnah;

g. ketentuan Pasal 20 ayat (2). Ketentuan lebih lanjut mengenai hapusnya Hak Guna Bangunan sebagaimana dimaksud dalam ayat (1) diatur dengan Keputusan Presiden. 
Pasal 20 Peraturan Pemerintah No. 40 Tahun 1996 menentukan: "Ayat (2) Apabila dalam jangka waktu sebagaimana dimaksud dalam ayat (1) haknya tidak dilepaskan atau dialihkan, hak tersebut hapus karena hukum".

Maksud dari pasal tersebut apabila tidak memenuhi syarat dalam jangka 1 tahun wajib melepaskan dan tidak memohon hak baru.

Jika kita konsisten dengan asas pemisahan horisontal yang dianut oleh UUPA, maka pemegang Hak Guna Bangunan atas Tanah Hak Milik dapat saja mengalihkan Hak Guna Bangunan tersebut kepada pihak lain tanpa memintah persetujuan secara tertulis kepada pemegang Hak Milik, karena objek yang dialihkan terpisah dangan Hak Milik atas tanah. Demikian juga sebaliknya Hak Milik atas tanah yang di atasnya dibebani dengan Hak Guna Bangunan, dapat beralih dan dialihkan. Hak Milik atas tanah yang di atasnya dibebani dengan Hak Guna Bangunan dapat beralih kepada ahli warisnya dan dapat pula dialihkan kepada orang lain. Peralihan hak milik dapat dilakukan dengan jual beli, tukar menukar, hibah, wasiat, dan lain-lain. Hak Milik atas tanah yang di atasnya dibebani Hak Guna Bangunan, maka peralihan hak tersebut secara fisik akan dilakukan setelah Hak Guna Bangunan yang ada di atas tanah Hak Milik telah berakhir. Dengan demikian peralihan Hak Milik atas tanah tidak menghapus Hak Guna Bangunan.

\section{c. Hak Guna Bangunan di atas Tanah Milik dapat dijadikan Jaminan Hutang dengan dibebani Hak Tanggungan}

Hak Guna Bangunan di atas tanah Hak Milik dapat dijadikan jaminan utang dengan dibebani Hak Tanggungan. Demikian pula halnya dengan Tanah Hak Milik yang di atasnya dibebani Hak Guna Bangunan juga dapat dijadikan jaminan utang dengan pembebanan Hak Tanggungan dan Hak Milik yang dibebani dengan Hak Tanggungan manakala terjadi kredit macet maka eksekusinya dan/atau penyerahannya akan dilakukan setelah Hak Guna Bangunan yang ada di atas Hak Milik berakhir. 
HGB atas tanah Hak Milik dapat dibebani Hak Tanggungan hal ini dapat dilakukan dengan cara pemberi dan penerima Hak Guna Bangunan atas tanah Hak Milik telah sepakat dalam akta pendahuluan, dimana penerima hak diberi kewenangan untuk menjaminkan dengan Hak Tanggungan oleh pemberi hak dengan dasar persetujuan tersebut selanjutnya penerima hak dapat membebani hak tanggungan tanpa harus mendapatkan persetujuan dari pemegang Hak Milik

Hapusnya HGB atas tanah Hak Milik yang sedang dibebani Hak Tanggungan karena jangka waktunya berakhir menyebabkan hapusnya Hak Tanggungan, namun tidak menghapuskan hutang debitur kepada kreditur. Kedudukan kreditur disini bukan lagi sebagai kreditur preferen tetapi kedudukan kreditur disini merupakan kreditur konkuren

\section{PENUTUP}

\section{Kesimpulan}

Berdasarkan pemeparan dari pembahasan di atas dapat ditarik berapa kesimpulan sebebagai berikut;

a. Pengaturan Pemberian Hak Guna Bangunan atas tanah hak milik pada dasarnya merupakan pembebanan yang dilakukan oleh pemegang hak milik atas tanah miliknya. Karena itu pemberian hak ini dilakukan dengan suatu perjanjian antara pemegang hak milik dan calon pemegang Hak Guna Bangunan yang dituangkan dalam akta yang dibuat oleh Pejabat Pembuat Akta Tanah.

b. Hak Guna Bangunan Atas Tanah Hak Milik mengatur soal saat terjadinya perjanjian, jangka waktu, peralihan, pembebanan Hak Tanggungan, dan pendaftarannya.

c. Beberapa Karakteristik Hak Guna Bangunan atas tanah hak milik, Pertama, HGB atas tanah Hak Milik dibatasi waktu yakni paling lama 30 tahun dan tidak dapat diperpanjang, namun dapat diperbaharui dan 
tunduk pada hukum privat. Kedua peralihan HGB di atas tanah Hak Milik karena jual beli, tukar menukar, penyertaan dalam modal, dan hibah harus dengan persetujuan tertulis terlebih dahulu dari pemegang hak milik dan harus dilakukan dengan akta yang dibuat oleh Pejabat Pembuat Akta Tanah.Peralihan HGB karena pewarisan harus dibuktikan dengan surat wasiat atau surat keterangan waris yang dibuat oleh instansi yang berwenang. Peralihan HGB atas tanah Hak Milik harus didaftarkan di Kantor Badan Pertanahan. Ketiga HGB atas tanah Hak Milik dapat dibebani Hak Tanggungan. Pada prinsipnya HGB atas tanah milik yang dibebani Hak Tanggungan harus mendapatkan persetujuan tertulis dari Pemegang Hak Milk, namun mengingat prinsip pemisahan horisontal dalam UUPA, maka pembebanan Hak Tanggungan terhadap HGB atas tanah hak milik dapat dilakukan tanpa persetujuan dari pemilik tanah. Hapusnya HGB atas tanah hak milik yang sedang dibebani hak Tanggungan karena jangka waktunya berakhir menyebabkan hapusnya Hak Tanggungan, namun tidak menghapuskan hak tagi dari kreditur. Kedudukan kreditur disini bukan lagi sebagai kreditur pemegang hak preperent tetapu menjadi kreditur biasa.

2. Saran.

Pemberian Hak Guna Bangunan atas Hak Milik sebaiknya diatur dalam peraturan perundang-undangan tersendiri baik dalam bentuk Undang-Undang, Peraturan Pemerintah atau dengan Keputusan Presiden, supaya dapat memberikan perlindungan hukum secara maksimal terhadap kedua belah pihak, baik kepada pemegang Hak Milik maupun pemegang Hak Guna Bangunan, jika sudah diatur secara rinci dan disosialisasikan dengan baik pasti pelaksanaanya juga akan baik pula. Hal ini mengacu apa yang diamanatkan oleh Pasal 24 ayat (4), dan Pasal 44 ayat (4) Peraturan Pemerintah Nomor 40 Tahun 1996, yang mengatakan bahwa Pemerintah hendaknya segera menerbitkan Keputusan Presiden yang mengatur mengenai tata cara pemberian dan pendaftaran Hak 
Guna Bangunan atas tanah Hak Milik. Mengingat esensi dari pemberian Hak Guna Bangunan atas Hak Milik adalah pemegang tanah Hak Milik masih mempunyai hak sepenuhnya atas tanah tersebut hanya saja diatas tanah yang dimilikinya masih bisa diusahakan oleh pihak lain dengan memperoleh Hak Guna Bangunan

\section{DAFTAR PUSTAKA}

Sutedi, Adrian ,Peralihan Hak Atas Tanah dan Pendaftarannya, Sinar Grafika, Jakarta.,2006,

Perangin, Effendi Hukum Agraria di Indonesia (Suatu Telaah dari Sudut Pandang Praktisi Hukum), Cetakan ke-3, Jakarta, Rajawali, 1991,

Ardiwilaga, R. Roestandi Hukum Agraria Indonesia Dalam Teori Dan Peaktek, Masa Baru, Bandung, 1060,

Mukjadi, Kartini dan Gunawan Widjaya, (II) Hak-Hak Atas Tanah. Kencana, Jakarta, 2007,

Ruchiyat, Eddy Politik Pertanahan,Alumni, Bandung 1989,

Kartasapoetra, G., Hukum Tanah, Rineka Cipta, Bandung, 1992,

\section{Peraturan Perundang-undangan.}

Undang-Undang Nomor 5 Tahun 1960, Tentang Peraturan Dasar Pokok-Pokok Agraria, Lembaran Negara Republik Indonesia 1960 Nomor 104, Tambahan Lembaran Negara Republik Indonesia Nomor 2043.

Undang-Undang Nomor 20 Tahun 1961 Tentang Pencabutan Hak-Hak Atas Tanah Dan Benda-Benda Yang Ada Di Atasnya, Lembaran Negara Republik Indonesia 1961 Nomor 228 Tambahan Lembaran Negara Republik Indonesia Nomor 2431

Undang-Undang Nomor 28 Tahun 2002 Tentang Bangunan Gedung, Lembaran Negara Republik Indonesia 2002 Nomor 134 Tambahan Lembaran Negara Republik Indonesia Nomor 4247.

Peraturan Pemerintah Nomor 40 Tahun 1996 Tentang Hak Guna Usaha, Hak Guna Bangunan Dan Hak Pakai Atas Tanah, Lembaran Negara Republik Indonesia 1996 Nomor 58, Tambahan Lembaran Negara Republik Indonesia Nomor 3643.

Peraturan Pemerintah Nomor 24 Tahun 1997 Tentang Pendaftaran Tanah, Lembaran Negara Republik Indonesia 1997 Nomor 50, Tambahan Lembaran Negara Republik Indonesia Nomor 3696. 